\title{
Comparative Analyses of Physiological Responses of Cynodon dactylon Accessions from Southwest China to Sulfur Dioxide Toxicity
}

\author{
Xi Li, ${ }^{1}$ Ling Wang, ${ }^{1}$ Yiqiao Li, ${ }^{2}$ Lingxia Sun, ${ }^{1}$ Shizhen Cai, ${ }^{1}$ and Zhuo Huang ${ }^{1}$ \\ ${ }^{1}$ College of Landscape Architecture, Sichuan Agricultural University, No. 211 Huimin Road, Wenjiang, \\ Sichuan 611130, China \\ ${ }^{2}$ Business School, Sichuan Agricultural University, Dujiangyan, Sichuan 611830, China
}

Correspondence should be addressed to Xi Li; 781221015@qq.com

Received 24 February 2014; Accepted 26 May 2014; Published 6 July 2014

Academic Editor: Mehmet Yakup Arica

Copyright (C) $2014 \mathrm{Xi} \mathrm{Li} \mathrm{et} \mathrm{al.} \mathrm{This} \mathrm{is} \mathrm{an} \mathrm{open} \mathrm{access} \mathrm{article} \mathrm{distributed} \mathrm{under} \mathrm{the} \mathrm{Creative} \mathrm{Commons} \mathrm{Attribution} \mathrm{License,} \mathrm{which}$ permits unrestricted use, distribution, and reproduction in any medium, provided the original work is properly cited.

\begin{abstract}
Sulfur dioxide $\left(\mathrm{SO}_{2}\right)$, a major air pollutant in developing countries, is highly toxic to plants. To achieve better air quality and landscape, planting appropriate grass species in severe $\mathrm{SO}_{2}$ polluted areas is very critical. Cynodon dactylon, a widely used warm season turfgrass species, has good $\mathrm{SO}_{2}$-tolerant ability. In this study, we selected 9 out of 38 C. dactylon accessions from Southwest China as representatives of high, intermediate $\mathrm{SO}_{2}$-tolerant and $\mathrm{SO}_{2}$-sensitive accessions to comparatively analyze their physiological differences in leaves under $\mathrm{SO}_{2}$ untreated and treated conditions. Our results revealed that $\mathrm{SO}_{2}$-tolerant $C$. dactylon accessions showed higher soluble sugar, proline, and chlorophyll a contents under both $\mathrm{SO}_{2}$ treated and untreated conditions; higher chlorophyll b and carotenoid under $\mathrm{SO}_{2}$ treated condition; lower reactive oxygen species (ROS) level, oxidative damages, and superoxide dismutase (SOD) activities under $\mathrm{SO}_{2}$ treated condition; and higher peroxidase (POD) activities under $\mathrm{SO}_{2}$ untreated condition. Further results indicated that $\mathrm{SO}_{2}$-tolerant $C$. dactylon accessions had higher sulfur contents under both $\mathrm{SO}_{2}$ treated and untreated conditions, consistent with higher $\mathrm{SO}$ activities under both $\mathrm{SO}_{2}$ treated and untreated conditions, and higher $\mathrm{SiR}$ activities under $\mathrm{SO}_{2}$ treated condition. Taken together, our results indicated that $\mathrm{SO}_{2}$ tolerance of $C$. dactylon might be largely related to soluble sugar, proline and chlorophyll a contents, and $\mathrm{SO}$ enzyme activity.
\end{abstract}

\section{Introduction}

Sulfur dioxide $\left(\mathrm{SO}_{2}\right)$, a gaseous pollutant with bad odor in the atmosphere, is mainly emitted from anthropogenic sources. It is estimated that more than $70 \%$ of global $\mathrm{SO}_{2}$ is emitted from anthropogenic sources, half of which is from combustion of fossil fuel [1]. With rapid development of economy in developing countries, emission of $\mathrm{SO}_{2}$ into the atmosphere has been increasing quickly. As the biggest developing country in the world, China is leading the world as the biggest $\mathrm{SO}_{2}$ emitter, contributing to about one-fourth of the global emission and more than $90 \%$ of East Asia emission since the 1990s [2]. Total $\mathrm{SO}_{2}$ emission in China increased by $53 \%$, from $21.7 \mathrm{Tg}\left(1 \mathrm{Tg}=10^{12} \mathrm{~g}\right)$ in 2000 to $33.2 \mathrm{Tg}$ in 2006 , at an annual growth rate of $7.3 \%$. The $\mathrm{SO}_{2}$ emission began to decrease after 2006 mainly due to the widespread application of flue-gas desulfurization (FGD) devices at all newly built thermal power units in order to implement a comprehensive national policy strategy of energy conservation and emission reduction since 2005. However, the total $\mathrm{SO}_{2}$ emissions are still very high $(27.7 \mathrm{Tg})$ in 2010 due to the dramatic growth of industrial production and energy consumption [3]. Thereafter, high level of $\mathrm{SO}_{2}$ in the atmosphere will be a major concern in developing countries in a long period of forthcoming time.

In the atmosphere, when gaseous $\mathrm{SO}_{2}$ meets with water, considerable amounts of $\mathrm{SO}_{2}$ are converted to sulphurous acid, which is the important component of acid rain. Sulfur is well known to be a basic constituent of sulfur-containing amino acids, iron-sulfur clusters, cofactors, polysaccharides, and lipids for all living organisms. $\mathrm{SO}_{2}$ can enter plants via their stomata by the process of photosynthesis and respiration [4]. Plant has the ability to incorporate this kind of inorganic sulfur into sulfur-containing amino acids, proteins, and 
glutathione (GSH) and sulfur can also serve as the sulfur precursor of sulfur-containing secondary products in plant. However, above a certain threshold, both $\mathrm{SO}_{2}$ and acid rain are highly toxic to plants, causing many visible symptoms in the plant like yellowing, chlorosis, bleaching, and even killing foliage depending on the dosages [4]. Because of the harmful effects of $\mathrm{SO}_{2}$, some plants cannot grow robustly and even die in severe polluted urban or industrial districts, creating "dead zones" without greenery. To achieve better air quality and landscape effect in such polluted areas, the plants with high resistance to $\mathrm{SO}_{2}$ should be selected out for use. Tree species tolerant to $\mathrm{SO}_{2}$ were selected out or developed for planting in air polluted areas [5-7].

Turfgrasses were extensively used in a sole manner or in combination with trees for environmental greening. Importantly, grass plants are more resistant to $\mathrm{SO}_{2}$ than woody plants, because the former have a higher $\mathrm{S}: \mathrm{C}$ ratio than the latter and therefore can take up more $\mathrm{SO}_{2}$ from the atmosphere [8]. Turfgrasses can be generally classified as cool season, warm season, or evergreen types. A few studies on tolerance to $\mathrm{SO}_{2}$ of cool-season grass populations in polluted areas have been carried out in the past decades. These studies mainly focused on identification of tolerant populations from cool-season species of Dactylis glomerata, Festuca rubra, Holcus lanatus, Lolium perenne, and Phleum bertolonii [9]; comparison of stomatal morphology and resistance, membrane permeability, and the uptake and metabolism of ${ }^{35} \mathrm{SO}_{3}$ and ${ }^{35} \mathrm{SO}_{2}$ in cool-season species of D. glomerata, F. rubra, $H$. lanatus, and L. perenne [10]; investigation on the rate of development of tolerance in cool-season species of F. rubra, L. multiflorum, L. perenne, P. pratense, and Poa pratensis [11]; and genetic nature of tolerance in cool-season species of L. perenne [12]. In such studies, Cynodon dactylon, a warm season perennial grass species, is not included, which is widely used as turfgrass on sports fields, golf courses, roadsides, and lawns in city or industry districts in warm season. Recently, our comparative study on physiological and growth performances found that $C$. dactylon displayed the highest resistance to $\mathrm{SO}_{2}$ among four warm season turfgrasses including C. dactylon, Eremochloa ophiuroides, Paspalum notatum, and Zoysia japonica [13]. In the present study, we firstly compared influences of $\mathrm{SO}_{2}$ on leaves of 38 wild C. dactylon accessions from Southwest China. Based on injury rate of $\mathrm{SO}_{2}$ to leaves, nine $C$. dactylon accessions representing high $\mathrm{SO}_{2}$-tolerant, intermediate $\mathrm{SO}_{2}$-tolerant, and $\mathrm{SO}_{2}$-sensitive to $\mathrm{SO}_{2}$ accessions were selected to comparatively study relationships between $\mathrm{SO}_{2}$ tolerance and several physiological parameters. This study gained some insights into understanding the genetic and molecular mechanisms of $C$. dactylon to $\mathrm{SO}_{2}$ and provided guideline for selection and development of C. dactylon variations for planting in $\mathrm{SO}_{2}$ polluted urban or industrial areas.

\section{Materials and Methods}

2.1. Plant Materials and Growth Conditions. Thirty-eight wild C. dactylon accessions used in this study were sampled from Sichuan Province, Chongqing municipality, Yunnan

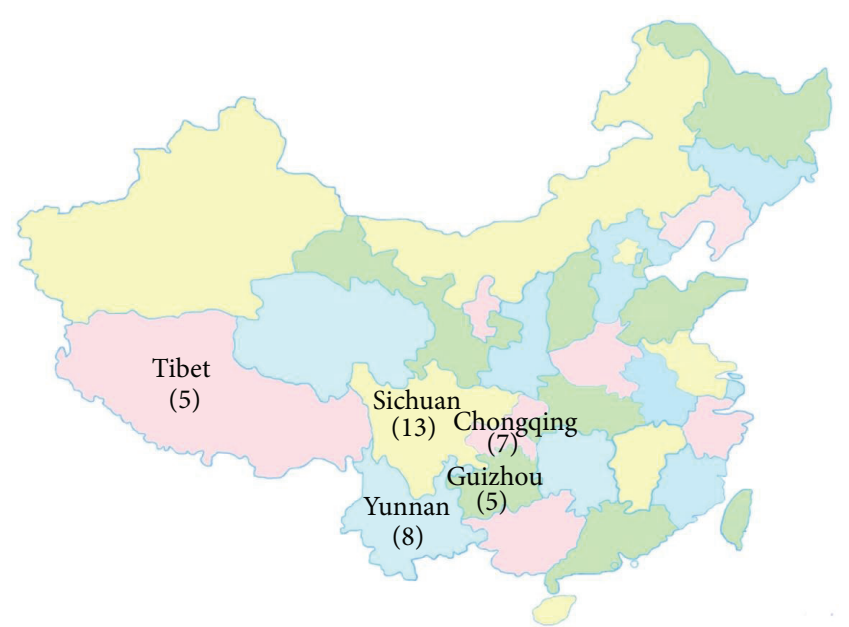

FIgURE 1: The collection sites of the 38 samples of wild C. dactylon in Southwest China. Provinces where samples were collected are illustrated with number of $C$. dactylon accessions in parentheses underneath in map.

Province, Guizhou Province, and Tibet Autonomous Region in Southwestern China between years 2011 and 2012. A complete list of accession descriptions and geographical origins was provided in Table 1 and Figure 1 . The wild $C$. dactylon accessions were collected originally from roadside, riverside, floodland, fieldridge, wasteland, hillside, or city park. All wild accessions used in this study were determined to be $C$. dactylon based on morphological characteristics as described by Harlan [14].

The experiments were carried out between April and August, 2013, at Experimental Station of Grass Science, Sichuan Agricultural University, Yảan, Sichuan Province, China. The experimental location is $600 \mathrm{~m}$ in altitude with a humid subtropical climate. Mean annual precipitation, annual temperature, and relative air humidity in the area are $1800 \mathrm{~mm}, 16.2^{\circ} \mathrm{C}$, and $79 \%$, respectively. All the C. dactylon accessions were planted in plastic pots $(18 \mathrm{~cm}$ in top diameter, $14 \mathrm{~cm}$ in bottom diameter, and $15 \mathrm{~cm}$ in depth) filled with typical sandy loam soil in the local place in April. Each $C$. dactylon accession was replicated six times. All C. dactylon grasses were grown under natural conditions for 2 months with regular watering every day and fertilizing and cutting every four weeks prior to the experimental treatment.

2.2. Stress Treatment and Experimental Design. After twomonth growth, three pots of grass plants with nearly the same crown from each accession were chosen from six replications (as mentioned above) for $\mathrm{SO}_{2}$ stress treatment. All of the selected pots of grass plants were fumigated with $\mathrm{SO}_{2}$ at a concentration of $3.75 \mathrm{mg} / \mathrm{L}$ in a custom-made fumigation chamber $(85 \mathrm{~cm} \times 85 \mathrm{~cm} \times 40 \mathrm{~cm})$ for $3 \mathrm{~h}$ per day over 7 days as described in our previous study [13]. The day when $\mathrm{SO}_{2}$ fumigation started was designated as day 0 . In order to achieve a uniform environment in the chamber, a fan was attached to the chamber ceiling to mix the $\mathrm{SO}_{2}$. $\mathrm{A} \mathrm{SO}_{2}$ gas detector (Z-1300, Environmental Sensors Co., Boca Raton, 
TABLE 1: Geographical origin of 38 wild C. dactylon accessions used in this study.

\begin{tabular}{|c|c|c|c|c|c|}
\hline Order & Accession number & Origin & Habitat & Altitude (m) & Mean annual temperature $\left({ }^{\circ} \mathrm{C}\right)$ \\
\hline 1 & SC1102 & Pixian, Sichuan & Roadside & 560 & 18.5 \\
\hline 2 & SC1105 & Longquan, Sichuan & Hillside & 750 & 16.5 \\
\hline 3 & SC1106 & Shuangliu, Sichuan & Riverside & 510 & 16.3 \\
\hline 4 & SC1109 & Guangyuan, Sichuan & Roadside & 490 & 16.1 \\
\hline 5 & SC1115 & Zitong, Sichuan & Roadside & 610 & 16.5 \\
\hline 6 & SC1119 & Guanghan, Sichuan & Riverside & 420 & 16.3 \\
\hline 7 & SC1201 & Leshan, Sichuan & Floodland & 420 & 17.4 \\
\hline 8 & SC1203 & Wuhou, Sichuan & City park & 540 & 16.7 \\
\hline 9 & SC1208 & Luxian, Sichuan & Riverside & 380 & 17.8 \\
\hline 10 & SC1209 & Nanchong, Sichuan & Hillside & 520 & 17.4 \\
\hline 11 & SC1211 & Guang'an, Sichuan & Roadside & 450 & 17.1 \\
\hline 12 & SC1213 & Panzhihua, Sichuan & Roadside & 1150 & 20.3 \\
\hline 13 & SC1217 & Meishan, Sichuan & Fieldridge & 460 & 17.1 \\
\hline 14 & CQ1101 & Jiangjin, Chongqing & Roadside & 590 & 18.4 \\
\hline 15 & CQ1102 & Yongchuan, Chongqing & Floodland & 340 & 18.2 \\
\hline 16 & CQ1107 & Bishan, Chongqing & Roadside & 530 & 18.3 \\
\hline 17 & CQ1108 & Jiangbei, Chongqing & Roadside & 440 & 17.5 \\
\hline 18 & CQ1109 & Dianjiang, Chongqing & Fieldridge & 420 & 17.0 \\
\hline 19 & CQ1112 & Liangping, Chongqing & Roadside & 520 & 16.6 \\
\hline 20 & CQ1116 & Wanzhou, Chongqing & Riverside & 180 & 17.7 \\
\hline 21 & YN1102 & Kunming, Yunnan & City park & 1910 & 15.0 \\
\hline 22 & YN1105 & Chuxiong, Yunnan & Roadside & 1790 & 15.8 \\
\hline 23 & YN1106 & Dali, Yunnan & Roadside & 1980 & 15.1 \\
\hline 24 & YN1107 & Lijiang, Yunnan & Riverside & 2360 & 15.8 \\
\hline 25 & YN1110 & Baoshan, Yunnan & Wasteland & 2410 & 16.0 \\
\hline 26 & YN1201 & Yuxi, Yunnan & Roadside & 1890 & 18.2 \\
\hline 27 & YN1205 & Pu'er, Yunnan & Roadside & 1750 & 17.7 \\
\hline 28 & YN1208 & Xishuangbanna, Yunnan & Roadside & 890 & 21.0 \\
\hline 29 & GZ1103 & Guiyang, Guizhou & Riverside & 970 & 15.3 \\
\hline 30 & GZ1104 & Anshun, Guizhou & Roadside & 860 & 14.0 \\
\hline 31 & GZ1106 & Liupanshui, Guizhou & Fieldridge & 1810 & 13.5 \\
\hline 32 & GZ1109 & Zunyi, Guizhou & Roadside & 960 & 15.1 \\
\hline 33 & GZ1110 & Qianlan, Guizhou & Hillside & 1050 & 16.1 \\
\hline 34 & XZ1205 & Lhasa, Tibet & Roadside & 3120 & 7.5 \\
\hline 35 & XZ1206 & Nyingchi, Tibet & Roadside & 3430 & 8.7 \\
\hline 36 & XZ1208 & Bomi, Tibet & Riverside & 2680 & 8.7 \\
\hline 37 & XZ1209 & Baxoi, Tibet & Roadside & 3250 & 10.4 \\
\hline 38 & $\mathrm{XZ1213}$ & Chamdo, Tibet & Floodland & 3170 & 7.6 \\
\hline
\end{tabular}

FL, USA) was used to measure the concentration of $\mathrm{SO}_{2}$ and to keep the gas concentration constant in the chamber during the experiment. After fumigation treatment, grass plants were taken out and grown under natural conditions with regular watering every day. The remaining three pots of grass plants without $\mathrm{SO}_{2}$ treatment from each accession served as control. Based on injury rate of $\mathrm{SO}_{2}$ to leaves after 7-day treatment of $\mathrm{SO}_{2}$, three high $\mathrm{SO}_{2}$-tolerant, three intermediate $\mathrm{SO}_{2}$ tolerant, and three $\mathrm{SO}_{2}$-sensitive $C$. dactylon accessions were selected out for physiological studies. Leaves $2 \mathrm{~cm}$ above the soil from C. dactylon plants treated by $\mathrm{SO}_{2}$ after 7 days were collected and brought back to laboratory for analysis. Leaves from C. dactylon plants without $\mathrm{SO}_{2}$ treatment at day 0 served as control.

2.3. Measurement of Total Soluble Sugars. The total soluble sugars were determined using the anthrone method as previously described by $\mathrm{Lu}$ et al. [15] with some modifications. Briefly, $0.2 \mathrm{mg}$ dried leaf samples were extracted in $5 \mathrm{~mL}$ of $80 \%(\mathrm{v} / \mathrm{v})$ ethanol at $80^{\circ} \mathrm{C}$ for $40 \mathrm{~min}$ and centrifuged at $15,000 \times \mathrm{g}$ for $10 \mathrm{~min}$. The pellets were further extracted twice with another $5 \mathrm{~mL}$ of $80 \%(\mathrm{v} / \mathrm{v})$ ethanol. The supernatants were combined together and depigmented by activated charcoal at $80^{\circ} \mathrm{C}$ for $30 \mathrm{~min}$. For the determination 
of soluble total sugars, $0.2 \mathrm{~mL}$ of the filtrate was mixed with $3 \mathrm{~mL}$ of $0.15 \%(\mathrm{w} / \mathrm{v})$ anthrone reagent $(0.3 \mathrm{~g}$ anthrone was dissolved in $200 \mathrm{~mL}$ of $7.74 \mathrm{M} \mathrm{H}_{2} \mathrm{SO}_{4}$ ) and then heated at $90^{\circ} \mathrm{C}$ for $20 \mathrm{~min}$. Finally, soluble total sugar level was determined at $620 \mathrm{~nm}$ of absorbance using a UV/VIS spectrophotometer Model 723PC (Jinghua Instruments, Shanghai, China).

2.4. Measurement of Proline Content. Proline content was estimated according to the method based on proline's reaction with ninhydrin described by Bates et al. [16] with modification. Briefly, $0.2 \mathrm{~g}$ leaf samples were ground in $5 \mathrm{~mL}$ $3 \%(\mathrm{w} / \mathrm{v})$ sulfosalicylic acid and then filtered through 0.45 $\mu \mathrm{m}$ filter paper. Two microliters of filtrate was mixed with equal volumes of ninhydrin reagent and glacial acetic acid. Well mixed solutions were boiled at $100^{\circ} \mathrm{C}$ for $1 \mathrm{~h}$. The reaction was terminated in an iced bath and the chromophore was extracted with $4 \mathrm{~mL}$ toluene and its absorbance at $520 \mathrm{~nm}$ was determined using a UV/VIS spectrophotometer Model 723PC (Jinghua Instruments, Shanghai, China).

2.5. Estimation of Chlorophyll and Carotenoid. Photosynthetic pigments from the leaves were extracted as described by Lichtenthaler and Wellburn [17] with modification. Leaf samples $(\sim 0.2 \mathrm{~g})$ were ground in $2 \mathrm{~mL}$ of $80 \%$ acetone and ethyl alcohol $(1: 1)$, using a mortar and pestle, and then filtered through $0.45 \mu \mathrm{m}$ filter paper. Absorbance of the resulting extracts was measured at three wavelengths 663, 646, and $470 \mathrm{~nm}$ for chlorophyll a, chlorophyll b, and carotenoids, respectively, using a UV/VIS spectrophotometer Model 723PC (Jinghua Instruments, Shanghai, China). The amounts of pigments were calculated according to the equations developed by Lichtenthaler and Wellburn [17]. Total chlorophyll was obtained from the sum of chlorophylls a + b.

2.6. Determination of $\mathrm{H}_{2} \mathrm{O}_{2}$ Level. For grass protein extraction, about $0.2 \mathrm{~g}$ fresh leaves were ground with liquid nitrogen and then homogenized in extraction buffer $(50 \mathrm{mM}$ sodium phosphate buffer, $\mathrm{pH} 7.8$ ). After centrifugation at $15,000 \times \mathrm{g}$ for $15 \mathrm{~min}$ at $4^{\circ} \mathrm{C}$, the supernatant was used for determination of $\mathrm{H}_{2} \mathrm{O}_{2}$ levels as described by $\mathrm{Hu}$ et al. [18]. Briefly, $1 \mathrm{~mL}$ of the supernatant was mixed with $1 \mathrm{~mL}$ of $0.1 \%$ titanium sulphate in $20 \% \mathrm{H}_{2} \mathrm{SO}_{4}(\mathrm{v} / \mathrm{v})$ thoroughly for $10 \mathrm{~min}$. After being centrifuged at $15,000 \times \mathrm{g}$ for $10 \mathrm{~min}$ at room temperature, the absorbance of the supernatant was measured at $410 \mathrm{~nm}$ using a UV/VIS spectrophotometer Model 723PC (Jinghua Instruments, Shanghai, China).

2.7. SOD, POD, CAT, SiR, and SO Enzyme Assays. Fresh leave sample $(\sim 0.5 \mathrm{~g})$ was homogenized in $5 \mathrm{~mL}$ of $0.1 \mathrm{M}$ phosphate buffer ( $\mathrm{pH}$ 6.8) containing $1 \mathrm{mM}$ EDTA, $1 \mathrm{mM}$ dithiothreitol, and $2 \%(\mathrm{w} / \mathrm{v})$ polyvinylpyrrolidone (PVP) using a chilled mortar and pestle on ice. The homogenate was centrifuged at $15,000 \times \mathrm{g}$ for $15 \mathrm{~min}$ at $4^{\circ} \mathrm{C}$, and the supernatant was used for enzyme activity. Soluble protein content was determined following the Bradford method [19] with BSA as standard. Superoxide dismutase (SOD) activity was determined spectrophotometrically at $560 \mathrm{~nm}$ based on the measurement of inhibition in the photochemical reduction of nitroblue tetrazolium (NBT) [20, 21]. Peroxidase (POD) activity was determined by the guaiacol oxidation method [22]. Catalase (CAT) activity was determined by measuring the rate of decomposition of $\mathrm{H}_{2} \mathrm{O}_{2}$ at $240 \mathrm{~nm}$, as described by Aebi [23]. Sulfite reductase ( $\mathrm{SiR}$ ) activity was estimated by the coupled SiR/OASTL assay $[24,25]$ with the addition of NADPH and tungstic acid [26]. Sulfite oxidase (SO) activity was determined by measuring sulphite disappearance using $\mathrm{OH}$ mediated discolouring of fuchsine according to Pachmayr's report [27].

2.8. Estimation of MDA Content. Malondialdehyde (MDA) content was determined using the method described by $\mathrm{Fu}$ and Huang [28]. Fresh leaf sample $(0.2 \mathrm{~g})$ was homogenized with $2 \mathrm{~mL}$ of $0.1 \%(\mathrm{w} / \mathrm{v})$ trichloroacetic acid (TCA) using a chilled mortar and pestle on ice. The homogenate was centrifuged at $15,000 \times \mathrm{g}$ for $20 \mathrm{~min}$, at $4^{\circ} \mathrm{C}$, and the supernatant was used for lipid peroxidation analysis. A total of $4 \mathrm{~mL}$ of $0.5 \%$ thiobarbituric acid (TBA) in $20 \%$ TCA was added to $1 \mathrm{~mL}$ of the supernatant. The mixture was incubated in hot water $\left(95^{\circ} \mathrm{C}\right)$ for $30 \mathrm{~min}$ and cooled immediately on ice to stop the reaction and centrifuged at $15,000 \times \mathrm{g}$ for $20 \mathrm{~min}$. Absorbance was measured at 532 and $600 \mathrm{~nm}$, and MDA concentration was estimated by subtracting the nonspecific absorption at $600 \mathrm{~nm}$ from the absorption at $532 \mathrm{~nm}$.

2.9. Estimation of Sulfur Content. For sulfur (S) determination, the turbidimetric method described by Reyes-Díaz et al. [29] was applied. Biomass of whole plant dried for $48 \mathrm{~h}$ was treated with $95 \%$ magnesium nitrate and ashed at $500^{\circ} \mathrm{C}$ for $8 \mathrm{~h}$. Then the ashed samples were digested in $10 \mathrm{~mL}$ of $2 \mathrm{M}$ $\mathrm{HCl}$ at $150^{\circ} \mathrm{C}$ for $60 \mathrm{~min}$. After addition of barium chloride $\left(\mathrm{BaCl}_{2}\right)$ and Tween-80 into the solution, its absorbance was immediately measured using a UV/VIS spectrophotometer Model 723PC (Jinghua Instruments, Shanghai, China) at $440 \mathrm{~nm}$.

2.10. Statistical Analysis. All experiments in this study were repeated at least three times. Statistical analysis (mean \pm standard error) was performed and chart was created using relative tools of Microsoft Excel 2010. All data were analyzed by ANOVA using SPSS 13.0 software package (SPSS Inc., Chicago, USA), and then LSD method was used to detect possible differences among the accessions. Asterisk symbols above the columns in the figures indicate significant differences at $P<0.05$ (Student's $t$-test).

\section{Results}

3.1. Leaf Injury under $\mathrm{SO}_{2}$ Stress Condition. After 7-day fumigation treatment by $\mathrm{SO}_{2}$, injury symptoms appeared on leaves of all the $38 \mathrm{C}$. dactylon accessions. The visible symptoms consisted of bifacial, marginal, or interval necrosis and chlorosis on leaves at the full stage of development (Figure 2). The necrotic areas ranged from white to brown in color, and the margins of the necrotic areas are mostly irregular and occasionally dark in color. Injury rate of leaves 


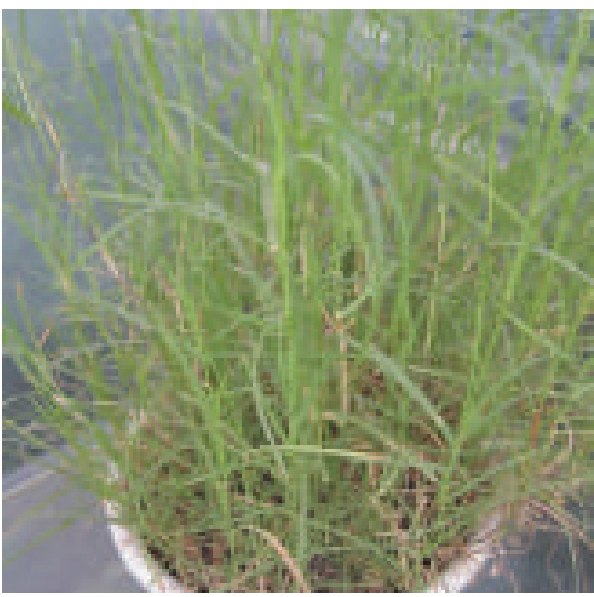

(a)

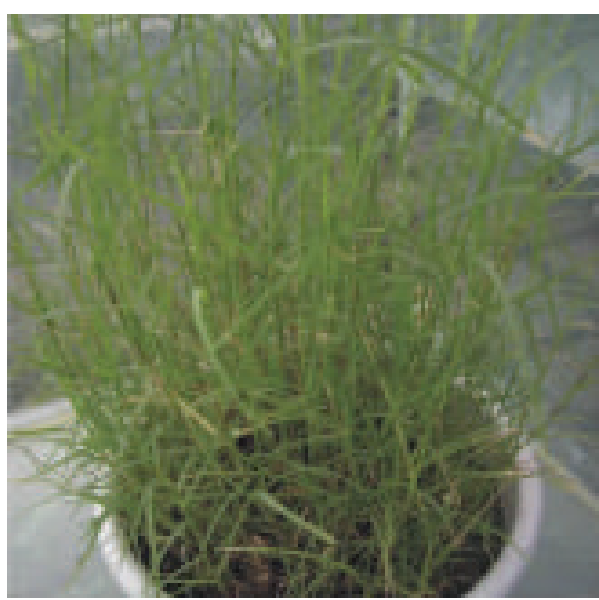

(c)

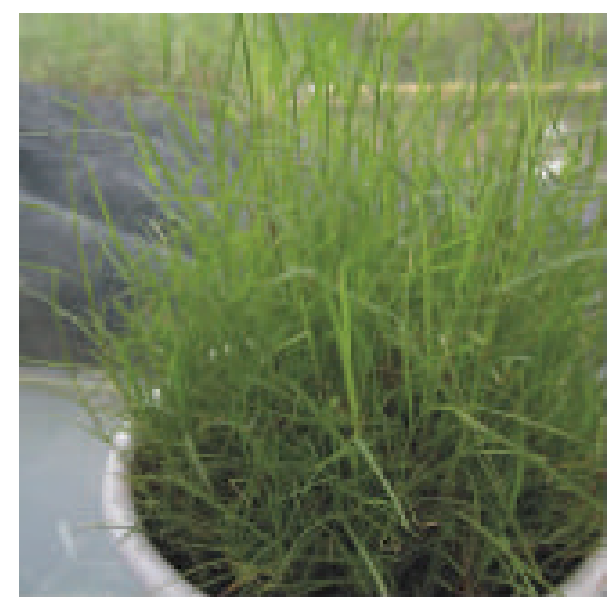

(b)

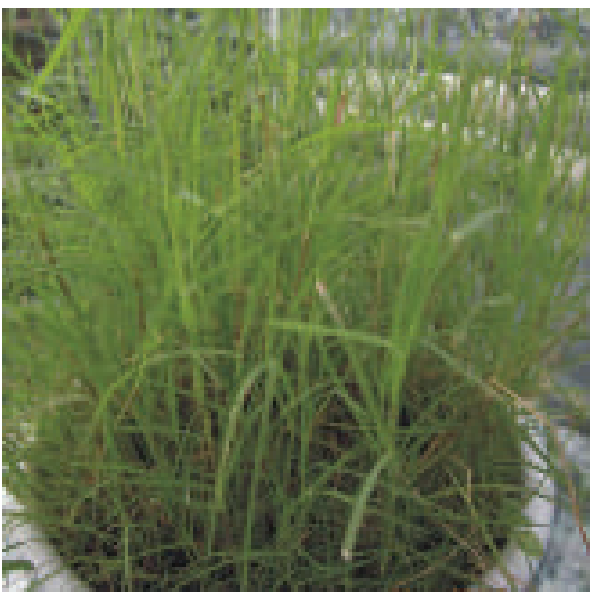

(d)

FIgure 2: Symptoms of C. dactylon accessions in response to $\mathrm{SO}_{2}$. (a) $\mathrm{SO}_{2}$-sensitive representative C. dactylon accession CQ1116, (b)

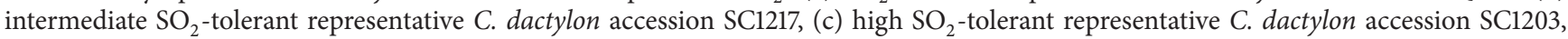
and (d) C. dactylon accession CQ1116 without $\mathrm{SO}_{2}$ treatment as a control.

varied in C. dactylon accessions from $38.3 \%$ in accession YN1205 to $13.3 \%$ in accession SC1203 (Table 2). It seemed that accessions originated from city park and hillside had higher $\mathrm{SO}_{2}$ tolerance than other habitat origins (Tables 1 and 2). To further study the physiological response of $C$. dactylon to $\mathrm{SO}_{2}$, we selected three accessions of SC1203, SC1209, and GZ1110 as high $\mathrm{SO}_{2}$-tolerant representatives, three accessions of SC1217, YN1110, and XZ1206 as intermediate $\mathrm{SO}_{2}$-tolerant representatives, and three accessions of YN1205, CQ1116, and SC1208 as $\mathrm{SO}_{2}$-sensitive representatives based on the injury rate of leaves and the geographic distribution (Tables 1 and 2).

\subsection{Changes of Sugar and Proline under $\mathrm{SO}_{2}$ Stress Condition.} The soluble sugar and proline contents in leaves from all of the nine $C$. dactylon accessions increased along with the increase of their $\mathrm{SO}_{2}$ tolerability (Figure 3). Moreover, the soluble sugar and proline contents from all of the high $\mathrm{SO}_{2}$ tolerant $C$. dactylon accessions and intermediate $\mathrm{SO}_{2}$-tolerant C. dactylon accessions were significantly higher than those from any of the three $\mathrm{SO}_{2}$-sensitive $C$. dactylon accessions at both 0-day time-point without $\mathrm{SO}_{2}$ treatment and 7-day timepoint after $\mathrm{SO}_{2}$ fumigation treatment. However, the soluble sugar and proline contents from 7-day time-point after $\mathrm{SO}_{2}$ fumigation treatment showed no significant change when they were compared with those from 0 -day time-point in any C. dactylon accession, which indicates that both soluble sugar and proline are not induced or inhibited in C. dactylon under $\mathrm{SO}_{2}$ stress condition (Figure 3 ).

3.3. Changes of Photosynthetic Pigments under $\mathrm{SO}_{2}$ Stress Condition. Contents of photosynthetic pigments in leaves from all of the nine $C$. dactylon accessions decreased under $\mathrm{SO}_{2}$ stress condition but showed different patterns with different pigment (Figure 4). Chlorophyll a contents from two intermediate $\mathrm{SO}_{2}$-tolerant $C$. dactylon accessions (YN1110 and XZ1206) and from all of the three high $\mathrm{SO}_{2}$-tolerant C. dactylon accessions were significantly higher than those from any of $\mathrm{SO}_{2}$-sensitive $C$. dactylon accessions in an increasing trend along with the increase of $\mathrm{SO}_{2}$ tolerability at 
TABLE 2: Leaf injury rate of 38 wild C. dactylon accessions under $\mathrm{SO}_{2}$ stress condition.

\begin{tabular}{|c|c|c|}
\hline Order & Accession number & Injury rate (\%) \\
\hline 1 & YN1205 & $38.3 \pm 0.6$ \\
\hline 2 & CQ1116 & $37.7 \pm 1.2$ \\
\hline 3 & SC1208 & $36.7 \pm 0.6$ \\
\hline 4 & SC1106 & $35.3 \pm 1.5$ \\
\hline 5 & GZ1109 & $34.3 \pm 1.5$ \\
\hline 6 & YN1107 & $32.0 \pm 1.7$ \\
\hline 7 & YN1208 & $31.7 \pm 0.6$ \\
\hline 8 & SC1213 & $30.3 \pm 1.5$ \\
\hline 9 & CQ1112 & $30.3 \pm 1.2$ \\
\hline 10 & XZ1209 & $28.7 \pm 1.2$ \\
\hline 11 & XZ1213 & $28.3 \pm 0.6$ \\
\hline 12 & GZ1104 & $27.3 \pm 1.5$ \\
\hline 13 & SC1119 & $26.3 \pm 1.5$ \\
\hline 14 & SC1201 & $26.3 \pm 2.1$ \\
\hline 15 & YN1106 & $25.7 \pm 1.5$ \\
\hline 16 & XZ1205 & $25.7 \pm 2.5$ \\
\hline 17 & CQ1102 & $25.3 \pm 0.6$ \\
\hline 18 & SC1217 & $25.3 \pm 1.5$ \\
\hline 19 & YN1110 & $25.0 \pm 1.0$ \\
\hline 20 & XZ1206 & $24.7 \pm 0.6$ \\
\hline 21 & SC1211 & $24.7 \pm 2.5$ \\
\hline 22 & YN1105 & $23.7 \pm 2.1$ \\
\hline 23 & XZ1208 & $23.0 \pm 1.7$ \\
\hline 24 & GZ1106 & $22.0 \pm 1.0$ \\
\hline 25 & SC1102 & $21.7 \pm 2.1$ \\
\hline 26 & SC1115 & $20.0 \pm 2.6$ \\
\hline 27 & CQ1108 & $20.0 \pm 2.6$ \\
\hline 28 & CQ1109 & $19.3 \pm 1.5$ \\
\hline 29 & YN1201 & $19.3 \pm 0.6$ \\
\hline 30 & SC1109 & $19.3 \pm 1.5$ \\
\hline 31 & GZ1103 & $19.0 \pm 2.0$ \\
\hline 32 & CQ1107 & $18.7 \pm 1.5$ \\
\hline 33 & CQ1101 & $17.7 \pm 1.5$ \\
\hline 34 & YN1102 & $17.3 \pm 1.5$ \\
\hline 35 & SC1105 & $16.3 \pm 1.5$ \\
\hline 36 & GZ1110 & $15.0 \pm 2.0$ \\
\hline 37 & SC1209 & $13.7 \pm 0.6$ \\
\hline 38 & SC1203 & $13.3 \pm 1.5$ \\
\hline
\end{tabular}

Note: data are presented by means \pm SE $(n=3)$.

0 -day time-point (Figure 4(a)). Under $\mathrm{SO}_{2}$ stress condition, chlorophyll a contents in leaves from intermediate and high $\mathrm{SO}_{2}$-tolerant $C$. dactylon accessions reduced significantly less than those from $\mathrm{SO}_{2}$-sensitive $C$. dactylon accessions. No significant differences of chlorophyll b contents were observed among the high $\mathrm{SO}_{2}$-tolerant, intermediate $\mathrm{SO}_{2}$ tolerant, and $\mathrm{SO}_{2}$-sensitive $C$. dactylon accessions at 0-day time-point (Figure 4(b)). After 7-day stress treatment by $\mathrm{SO}_{2}$ fumigation, chlorophyll $\mathrm{b}$ contents reduced in leaves from all of the nine C. dactylon accessions. The contents of chlorophyll b showed no significant differences between intermediate
$\mathrm{SO}_{2}$-tolerant and $\mathrm{SO}_{2}$-sensitive $C$. dactylon accessions, but significantly less reduction of chlorophyll b content was observed in high $\mathrm{SO}_{2}$-tolerant $C$. dactylon accessions. As for total chlorophyll content, it showed a similar pattern with chlorophyll a in leaves from all of the nine $C$. dactylon accessions (Figure 4(c)). Carotenoid contents showed no significant differences among the high $\mathrm{SO}_{2}$-tolerant, intermediate $\mathrm{SO}_{2}$-tolerant, and $\mathrm{SO}_{2}$-sensitive $C$. dactylon accessions at 0 -day time-point but significantly less reduced along with the increase of $\mathrm{SO}_{2}$ tolerability of $C$. dactylon accessions after 7-day $\mathrm{SO}_{2}$ stress treatment (Figure $4(\mathrm{~d})$ ).

3.4. Changes of ROS Level and Antioxidant Enzyme Activities under $\mathrm{SO}_{2}$ Stress Condition. As two major indicators for reactive oxygen species (ROS) level and oxidative damage, hydrogen peroxide $\left(\mathrm{H}_{2} \mathrm{O}_{2}\right)$ and malondialdehyde (MDA) contents were tested in this study. As shown in Figure 5, the high $\mathrm{SO}_{2}$-tolerant, intermediate $\mathrm{SO}_{2}$-tolerant, and $\mathrm{SO}_{2}$ sensitive $C$. dactylon accessions displayed nearly the same levels of $\mathrm{H}_{2} \mathrm{O}_{2}$ and $\mathrm{MDA}$ in leaves at 0-day time-point without $\mathrm{SO}_{2}$ treatment (Figures 5(a) and 5(b)). After 7-day $\mathrm{SO}_{2}$ fumigation treatment, levels of both $\mathrm{H}_{2} \mathrm{O}_{2}$ and MDA increased in leaves from all of the nine C. dactylon accessions. When compared within all of the nine $C$. dactylon accessions, levels of both $\mathrm{H}_{2} \mathrm{O}_{2}$ and $\mathrm{MDA}$ in leaves from high $\mathrm{SO}_{2}$ tolerant $C$. dactylon accessions and intermediate $\mathrm{SO}_{2}$-tolerant C. dactylon accessions were significantly lower than those from $\mathrm{SO}_{2}$-sensitive $C$. dactylon accessions (Figures 5(a) and 5(b)).

To address the relationship between the changes of ROS level and the antioxidant enzyme activities, three major antioxidant enzymes, including SOD, POD, and CAT, were analyzed for their enzyme activities. SOD activities showed no significant differences (about $30 \mathrm{U} / g$ protein $\mathrm{FW}$ ) in leaves from high $\mathrm{SO}_{2}$-tolerant $C$. dactylon accessions, intermediate $\mathrm{SO}_{2}$-tolerant $C$. dactylon accessions, and $\mathrm{SO}_{2}$-sensitive C. dactylon accessions at 0-day time-point without $\mathrm{SO}_{2}$ treatment (Figure 6(a)). After 7-day $\mathrm{SO}_{2}$ stress treatment, SOD activities increased greatly in leaves from all of the nine $C$. dactylon accessions. However, the increase degree was in a decreasing trend along with $\mathrm{SO}_{2}$ tolerability of the C. dactylon accessions, displaying highest activities in $\mathrm{SO}_{2}$ sensitive $C$. dactylon accessions (more than $120 \mathrm{U} / g$ protein FW) and lowest activities in high $\mathrm{SO}_{2}$-tolerant $C$. dactylon accessions (more than $60 \mathrm{U} / \mathrm{g}$ protein $\mathrm{FW}$ ) (Figure 6(a)). POD activities increased in leaves from all of the nine $C$. dactylon accessions after 7-day $\mathrm{SO}_{2}$ stress treatment, but no significant differences were observed within high $\mathrm{SO}_{2}$ tolerant $C$. dactylon accessions, intermediate $\mathrm{SO}_{2}$-tolerant $C$. dactylon accessions, and $\mathrm{SO}_{2}$-sensitive $C$. dactylon accessions (Figure 6(b)). However, we found that POD activities in leaves from $\mathrm{SO}_{2}$-tolerant $C$. dactylon accessions were significantly higher than those from $\mathrm{SO}_{2}$-sensitive $C$. dactylon accessions in an increasing trend along with an increase of $\mathrm{SO}_{2}$ tolerability at 0-day time-point without $\mathrm{SO}_{2}$ treatment, displaying nearly 1.4 -fold increase $(15433 / 11183 \mathrm{U} / \mathrm{g}$ protein FW) and 1.7-fold increase (18866/11183 U/g protein FW) of enzyme activities in intermediate $\mathrm{SO}_{2}$-tolerant and 


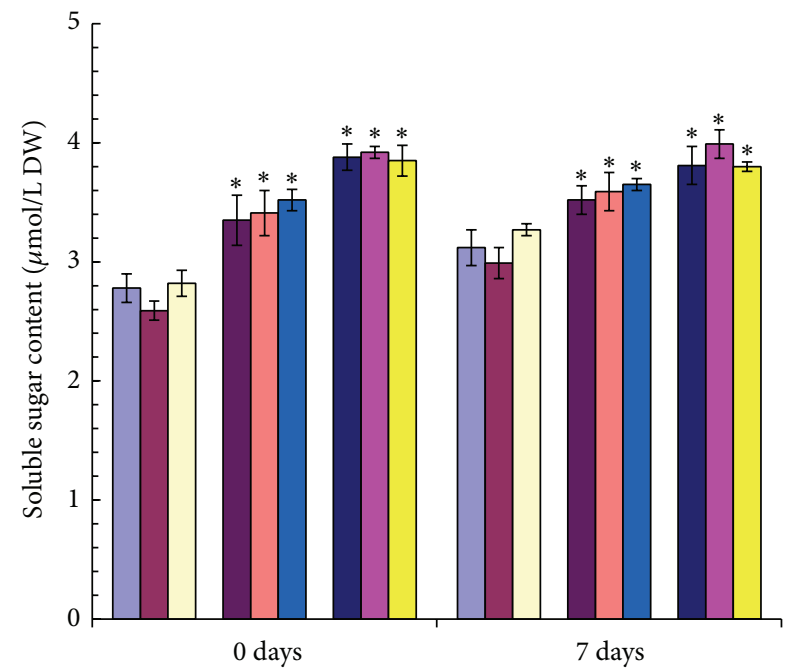

(a)

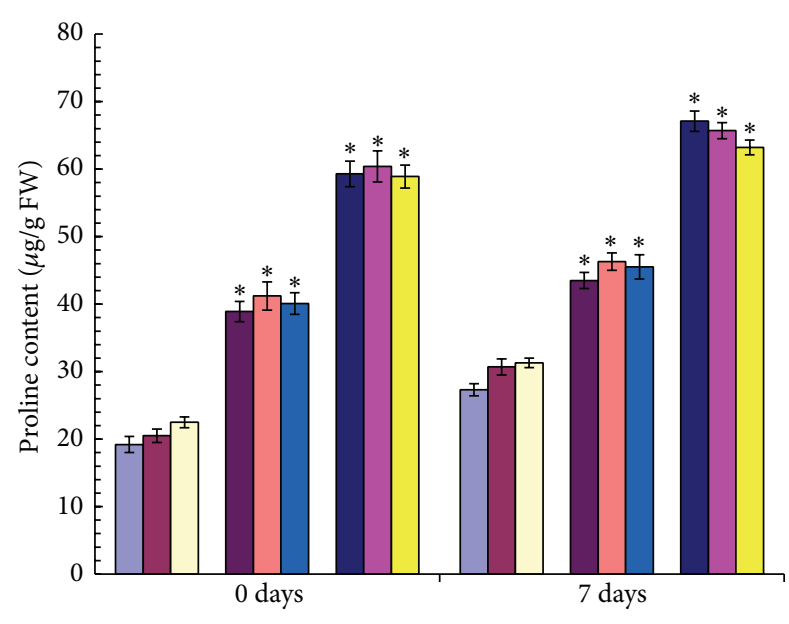

$\square$ YN1205
$\square$ XZ1206
$\square$ CQ1116
$\square$ SC1203
$\square$ SC1209

SC1209

SC1217

GZ1110

YN1110

(b)

FIGURE 3: Comparison of soluble sugar (a) and proline (b) in leaves from nine selected C. dactylon accessions in response to $\mathrm{SO}_{2}$ stress. $\mathrm{Mean}$ values are presented with vertical error bars representing the standard deviations $(n=3)$. The asterisk symbols indicate significant differences between $\mathrm{SO}_{2}$-sensitive accessions and $\mathrm{SO}_{2}$-tolerant accessions.

high $\mathrm{SO}_{2}$-tolerant $C$. dactylon accessions, respectively (Figure 6(b)). CAT activities increased in leaves from all of the nine $C$. dactylon accessions after 7-day $\mathrm{SO}_{2}$ stress treatment, but no significant differences were observed in leaves from high $\mathrm{SO}_{2}$-tolerant $C$. dactylon accessions, intermediate $\mathrm{SO}_{2}$-tolerant $C$. dactylon accessions, and $\mathrm{SO}_{2}$ sensitive $C$. dactylon accessions either after 7-day $\mathrm{SO}_{2}$ stress treatment or at 0-day without $\mathrm{SO}_{2}$ treatment (Figure 6(c)).

\subsection{Changes of Sulfur Content, SiR, and SO Enzyme Activ-} ities under $\mathrm{SO}_{2}$ Stress Condition. Sulfur contents in leaves from two intermediate $\mathrm{SO}_{2}$-tolerant $C$. dactylon accessions (YN1110 and XZ1206) and all of the three high $\mathrm{SO}_{2}$-tolerant $C$. dactylon accessions were significantly higher than those from any of the $\mathrm{SO}_{2}$-sensitive $C$. dactylon accessions at 0-day timepoint without $\mathrm{SO}_{2}$ stress treatment (Figure 7(a)). After 7-day $\mathrm{SO}_{2}$ fumigation treatment, sulfur contents increased in leaves from all of the nine $C$. dactylon accessions in an increasing trend along with increase of $\mathrm{SO}_{2}$ tolerability of the $C$. dactylon accessions. Moreover, sulfur contents in leaves from all of the high and intermediate $\mathrm{SO}_{2}$-tolerant $C$. dactylon accessions showed significantly higher levels than those from any of the $\mathrm{SO}_{2}$-sensitive $C$. dactylon accessions (Figure $7(\mathrm{a})$ ). SiR activities were nearly in the same levels (about $5 \mathrm{U} / \mathrm{mg}$ protein FW) in leaves from all of the nine $C$. dactylon accessions at 0 -day time-point without $\mathrm{SO}_{2}$ treatment (Figure 7(b)). After 7-day $\mathrm{SO}_{2}$ stress treatment, $\mathrm{SiR}$ activities increased about 2fold (approximate $10 \mathrm{U} / \mathrm{mg}$ protein $\mathrm{FW}$ ) in $\mathrm{SO}_{2}$-sensitive $C$. dactylon accessions, 2.4-fold (approximate $12 \mathrm{U} / \mathrm{mg}$ protein $\mathrm{FW}$ ) in intermediate $\mathrm{SO}_{2}$-tolerant $C$. dactylon accessions, and 3.4-fold (approximate $17 \mathrm{U} / \mathrm{mg}$ protein $\mathrm{FW}$ ) in high $\mathrm{SO}_{2}$ tolerant $C$. dactylon accessions, respectively. More importantly, SiR activities showed significantly higher levels in leaves from high and intermediate $\mathrm{SO}_{2}$-tolerant $C$. dactylon accessions than those from $\mathrm{SO}_{2}$-sensitive $C$. dactylon accessions, displaying an apparent increasing trend along with $\mathrm{SO}_{2}$ tolerability of the C. dactylon accessions (Figure 7(b)). SO activities in leaves from any of $C$. dactylon accessions after 7day $\mathrm{SO}_{2}$ fumigation treatment showed nearly the same level with those from 0 -day time-point without $\mathrm{SO}_{2}$ treatment (Figure 7(c)). However, SO activity levels were significantly higher in leaves from high and intermediate $\mathrm{SO}_{2}$-tolerant C. dactylon accessions than those from $\mathrm{SO}_{2}$-sensitive $C$. dactylon accessions, displaying an apparent increasing trend along with $\mathrm{SO}_{2}$ tolerability of the $C$. dactylon accessions (Figure 7(c)).

\section{Discussion}

$\mathrm{SO}_{2}$, a major air pollutant in developing countries, is highly toxic to plants once they are exposed to high doses of $\mathrm{SO}_{2}$ above the threshold. C. dactylon is a widely used warm season turfgrass on sports fields, golf courses, roadsides, and lawns in city or industry districts. Our previous study indicated that growth rate of $C$. dactylon was affected and visible symptoms appeared on leaves under $\mathrm{SO}_{2}$ stress condition; however this species has much better $\mathrm{SO}_{2}$-tolerant ability among warm season turfgrasses [13]. C. dactylon is wildly distributed in South America, Africa, Europe, and South Asia 


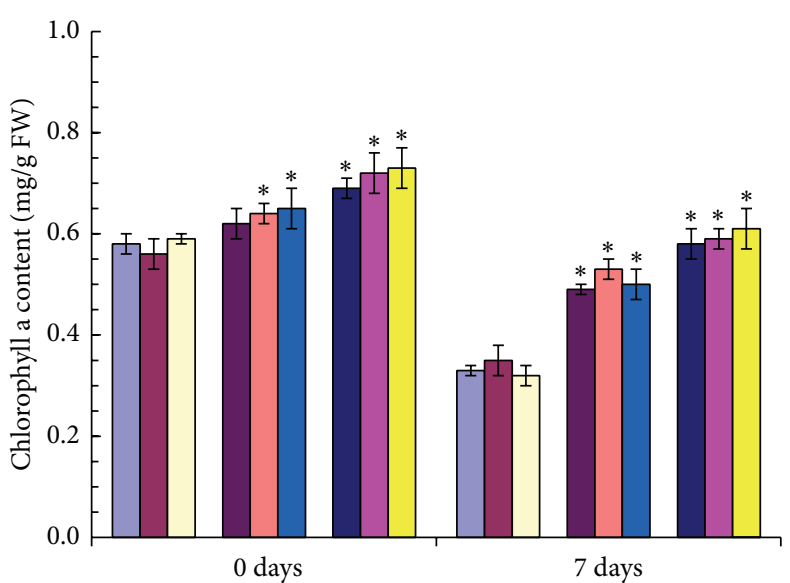

(a)

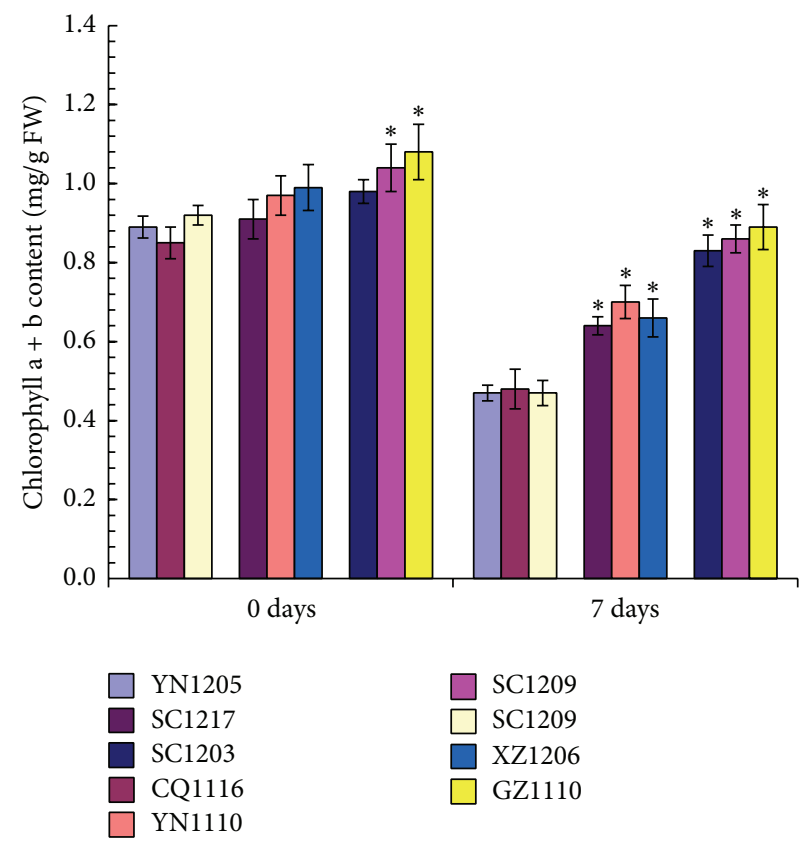

(c)

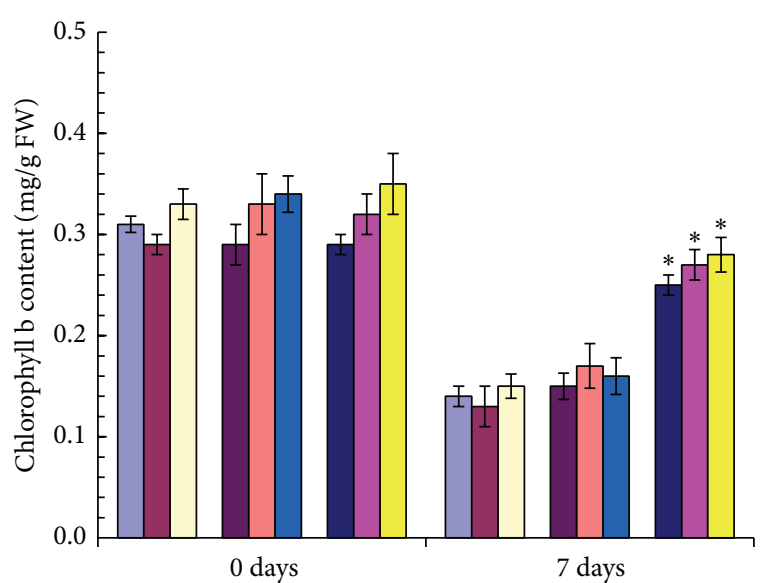

(b)

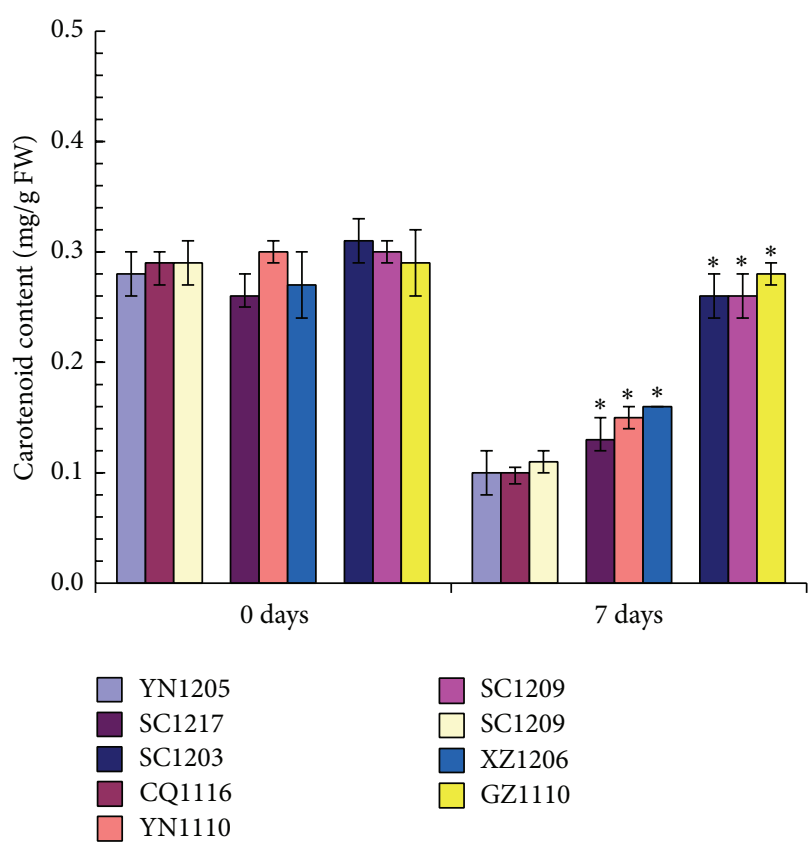

(d)

FIGURE 4: Comparison of chlorophyll a (a), chlorophyll b (b), total chlorophyll (c), and carotenoid (d) in leaves from nine selected C. dactylon accessions in response to $\mathrm{SO}_{2}$ stress. Mean values are presented with vertical error bars representing the standard deviations $(n=3)$. The asterisk symbols indicate significant differences between $\mathrm{SO}_{2}$-sensitive accessions and $\mathrm{SO}_{2}$-tolerant accessions.

and displays abundant genetic diversities worldwide [3033]. To achieve better air quality and landscape effect in $\mathrm{SO}_{2}$ polluted areas, selection or development of high $\mathrm{SO}_{2}$ tolerant $C$. dactylon variations for planting in such regions is desired. In this study, we selected 9 out of 38 wild $C$. dactylon accessions from Southwest China as representatives of high, intermediate $\mathrm{SO}_{2}$-tolerant, and $\mathrm{SO}_{2}$-sensitive accessions based on the injury degree of $\mathrm{SO}_{2}$ to leaves and the geographic distribution and then comparatively analyzed their physiological differences under $\mathrm{SO}_{2}$ untreated and treated conditions. Our results indicated that $\mathrm{SO}_{2}$ tolerance of C. dactylon might be largely related to soluble sugar, proline and chlorophyll a contents, and SO enzyme activities. To the best of our knowledge, this is the first comprehensive study of physiological differences in C. dactylon accessions of warm season turfgrasses. This study gained some insights into understanding the genetic and molecular $\mathrm{SO}_{2}$-tolerant mechanisms of $C$. dactylon and provided guideline for selection and development of $C$. dactylon variations for planting in $\mathrm{SO}_{2}$ polluted urban or industrial areas.

Soluble sugars and proline, as two major compatible solutes in the cytoplasm and organelle, play important roles under multiple stress conditions, such as drought and salinity $[34,35]$. In this study, we observed that $\mathrm{SO}_{2}$-tolerant $C$. dactylon accessions showed significantly higher soluble sugar and proline contents under both $\mathrm{SO}_{2}$ treated and untreated conditions (Figure 3), suggesting that both of them might be related to $\mathrm{SO}_{2}$ tolerance. C. dactylon accessions originated 

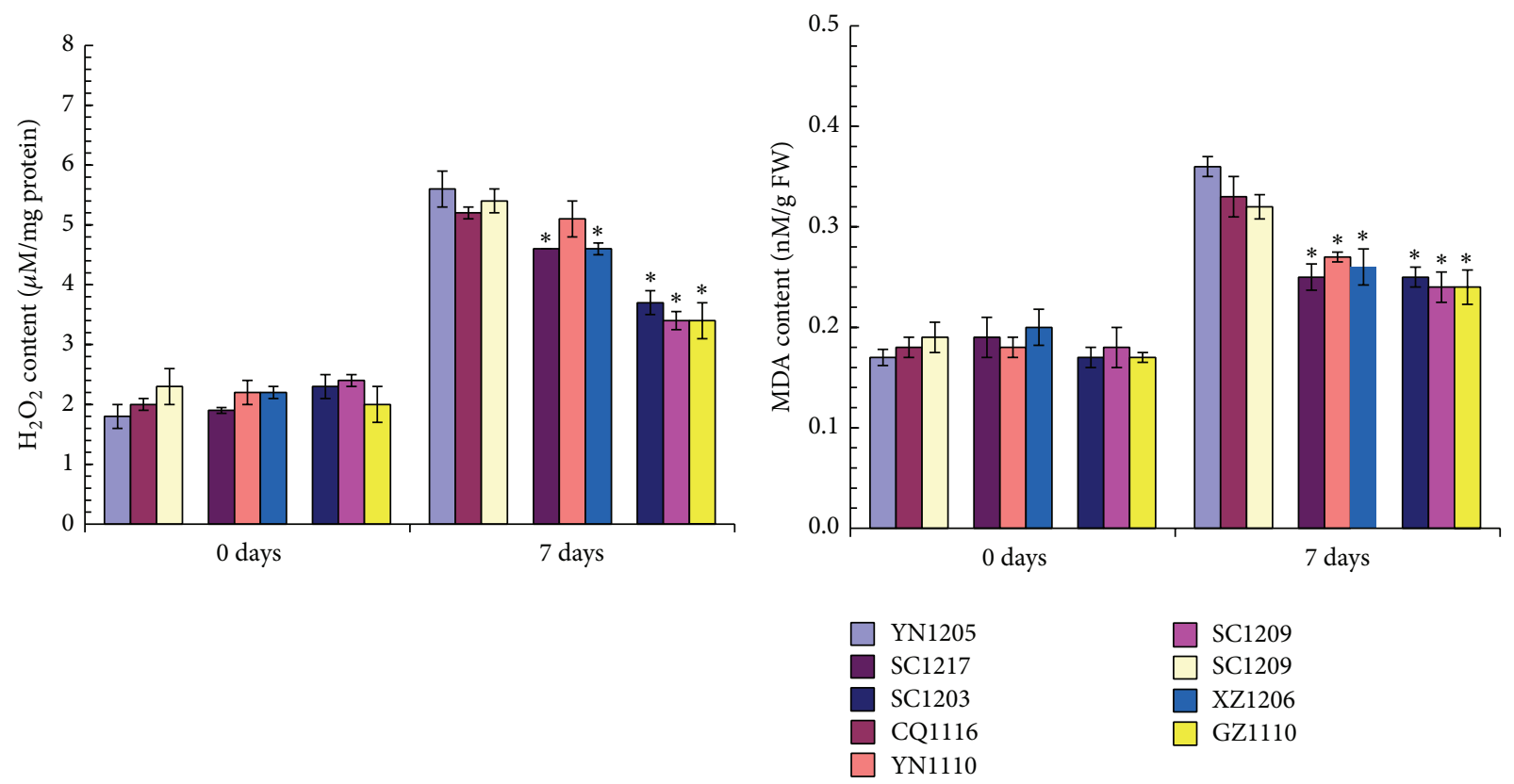

(a)

(b)

Figure 5: Comparison of ROS levels reflected by $\mathrm{H}_{2} \mathrm{O}_{2}$ (a) and MDA (b) contents in leaves from nine selected C. dactylon accessions in response to $\mathrm{SO}_{2}$ stress. Mean values are presented with vertical error bars representing the standard deviations $(n=3)$. The asterisk symbols indicate significant differences between $\mathrm{SO}_{2}$-sensitive accessions and $\mathrm{SO}_{2}$-tolerant accessions.

from habitats of hillside and city park have much higher $\mathrm{SO}_{2}$ tolerance than those from other habitats (Tables 1 and 2), suggesting that the increased soluble sugar and proline contents most probably evolved from drought and $\mathrm{SO}_{2}$ stress adaptation. However, increased soluble sugar and proline contents in $\mathrm{SO}_{2}$-tolerant $C$. dactylon accessions are not likely involved in osmotic pressure but more likely involved in maintaining cell membrane stability, synthesis of other compounds, supply of energy, action as regulators of gene expression, and signal molecules based on their multiple functions [36]. Thereafter, soluble sugar and proline contents can be considered as marker for selection of $C$. dactylon variations with high $\mathrm{SO}_{2}$ tolerability.

Chlorophyll (including chlorophylls $\mathrm{a}$ and $\mathrm{b}$ ) and carotenoid are known as the two important pigments in chloroplast of tree and grass plant leaves. The important role of pigments is to absorb certain wavelengths from sunlight and then convert the unusable sunlight energy into usable chemical energy during photosynthesis. Chlorophyll a is the primary pigment for photosynthesis in plants [37]. In this study, leaf injury of $C$. dactylon was observed under $\mathrm{SO}_{2}$ stress condition (Table 2). As a consequence, chlorophyll a, chlorophyll $\mathrm{b}$, and carotenoid contents decreased in $C$. dactylon under $\mathrm{SO}_{2}$ stress condition, consistent with previous reports on grass and tree plants $[13,38,39]$. However, $\mathrm{SO}_{2}$-tolerant C. dactylon accessions showed significantly higher contents of chlorophyll a, chlorophyll b, and carotenoid under $\mathrm{SO}_{2}$ treated condition, consistent with their less leaf injury $\mathrm{SO}_{2}-$ tolerant $C$. dactylon accessions observed in this study. Moreover, $\mathrm{SO}_{2}$-tolerant $C$. dactylon accessions had significantly higher content of chlorophyll a under $\mathrm{SO}_{2}$ untreated condition. Now that chlorophyll a is the primary pigment for photosynthesis in plants, significantly higher contents of chlorophyll a in C. dactylon accessions under both $\mathrm{SO}_{2}$ treated and untreated conditions indicate that $\mathrm{SO}_{2}$ tolerance of $C$. dactylon might be largely related to content of chlorophyll a.

Early study showed that $\mathrm{SO}_{2}$ gas after entering leaves of plant is converted into sulfite $\left(\mathrm{SO}_{3}{ }^{2-}\right)$ and bisulfite $\left(\mathrm{HSO}_{3}{ }^{2-}\right)$ once it is dissolved in cellular cytoplasm [40]. Furthermore, detoxification reaction of $\mathrm{HSO}_{3}{ }^{2-}$ and $\mathrm{SO}_{3}{ }^{2-}$ to sulfate $\left(\mathrm{SO}_{4}{ }^{2-}\right)$ in plants leads to production of many kinds of $\mathrm{ROS}$, such as superoxide radical $\left(\mathrm{O}^{-*}\right)$, hydrogen peroxide $\left(\mathrm{H}_{2} \mathrm{O}_{2}\right)$, and hydroxyl radical $\left(\mathrm{OH}^{*}\right)$ [41]. Excessive ROS are highly reactive and toxic to plants, which could cause oxidative damage to membranes, DNA, proteins, photosynthetic pigments, and lipids [42]. To protect plant cells from ROS damage, plant developed antioxidant enzymes to deal with the excessive ROS in plant cells. SOD, POD, and CAT are considered as three major antioxidant enzymes. To analyze the oxidative effect of $\mathrm{SO}_{2}$ on C. dactylon, we measured the ROS level and antioxidant enzyme activities in C. dactylon accessions. Although both ROS levels (reflected by $\mathrm{H}_{2} \mathrm{O}_{2}$ and MDA contents) and antioxidant enzyme activities (reflected by SOD, POD, and CAT) increased in all of the nine C. dactylon accessions under $\mathrm{SO}_{2}$ stress condition, the $\mathrm{SO}_{2}$-tolerant C. dactylon accessions showed significantly lower ROS levels and SOD activities, indicating that the $\mathrm{SO}_{2}$-tolerant $C$. dactylon accessions have much stronger antioxidant ability and less damage occurs to them by $\mathrm{SO}_{2}$. Moreover, lower SOD activity was theoretically consistent with lower ROS 


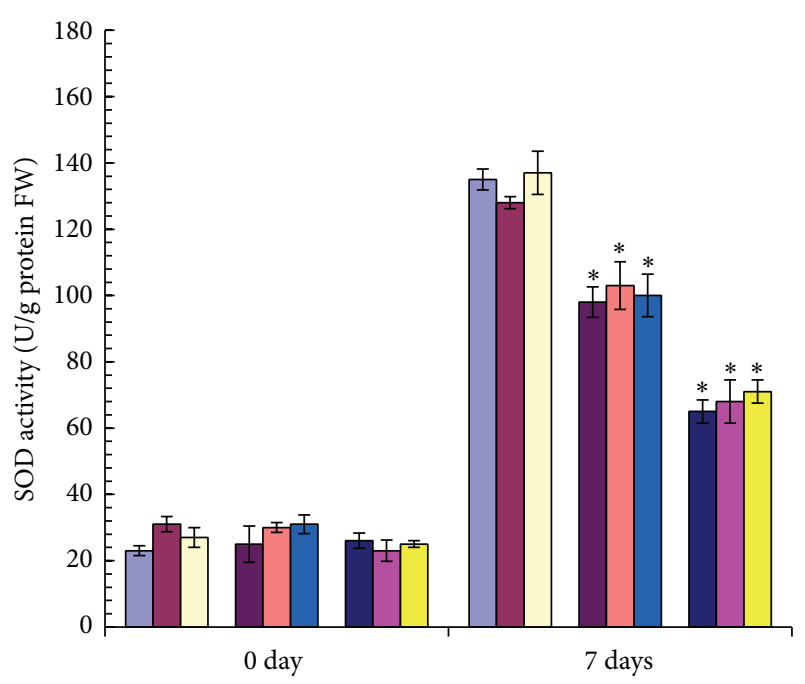

(a)

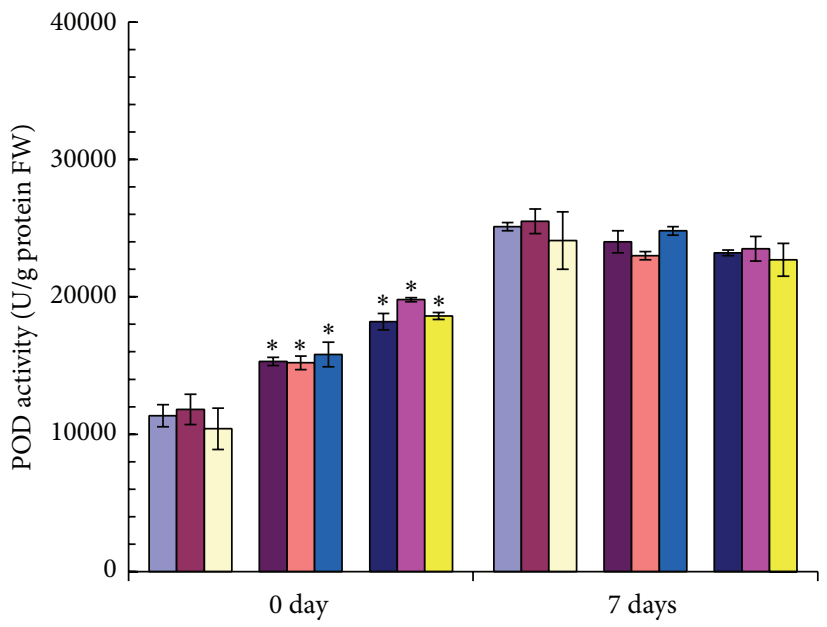

(b)

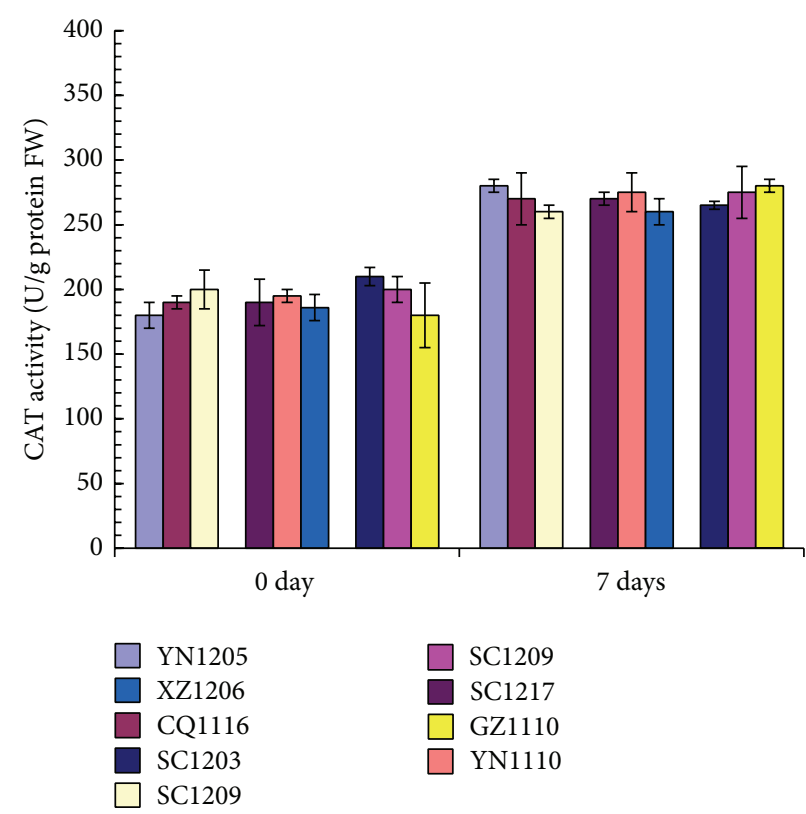

(c)

FIgURE 6: Comparison of antioxidant enzyme activities in leaves from C. dactylon accessions in response to $\mathrm{SO}_{2}$ stress. Antioxidant enzyme activities of SOD (a), POD (b), and CAT (c) in leaves from nine selected C. dactylon accessions in response to $\mathrm{SO}_{2}$ stress were compared. Mean values are presented with vertical error bars representing the standard deviations $(n=3)$. The asterisk symbols indicate significant differences between $\mathrm{SO}_{2}$-sensitive accessions and $\mathrm{SO}_{2}$-tolerant accessions.

level in the $\mathrm{SO}_{2}$-tolerant $C$. dactylon accessions under $\mathrm{SO}_{2}$ stress condition, which is in agreement with previous report [43]. Although POD activities were nearly at the same level in leaves from all of the nine $C$. dactylon accessions after 7day $\mathrm{SO}_{2}$ stress treatment, activities of this antioxidant enzyme from $\mathrm{SO}_{2}$-tolerant $C$. dactylon accessions were significantly higher than those from $\mathrm{SO}_{2}$-sensitive $C$. dactylon accessions. Taken together, we suggest that significantly higher activity of POD prior to $\mathrm{SO}_{2}$ treatment might be devoted to the increased antioxidant ability in $\mathrm{SO}_{2}$-tolerant $C$. dactylon accessions.
$\mathrm{SO}_{2}$ gas after entering leaves of plant can be converted into either sulfate by $\mathrm{SO}$ to enter into oxidative pathway or sulfide by $\mathrm{SiR}$ to enter into reductive pathway [44]. Overexpression of both $\mathrm{SO}$ and $\mathrm{SiR}$ showed more tolerance to sulfur dioxide toxicity in Arabidopsis thaliana and/or tomato plants [44-47]. Transcriptional analyses indicate that $\mathrm{SiR}$ is induced by $\mathrm{SO}_{2}$ but $\mathrm{SO}$ is constitutively expressed in natural plant $[45,46]$. In this study, we found that $\mathrm{SiR}$ activity level was significantly increased under $\mathrm{SO}_{2}$ stress condition but $\mathrm{SO}$ activity level had almost no change under $\mathrm{SO}_{2}$ treated and untreated conditions in leaves from all of the nine 


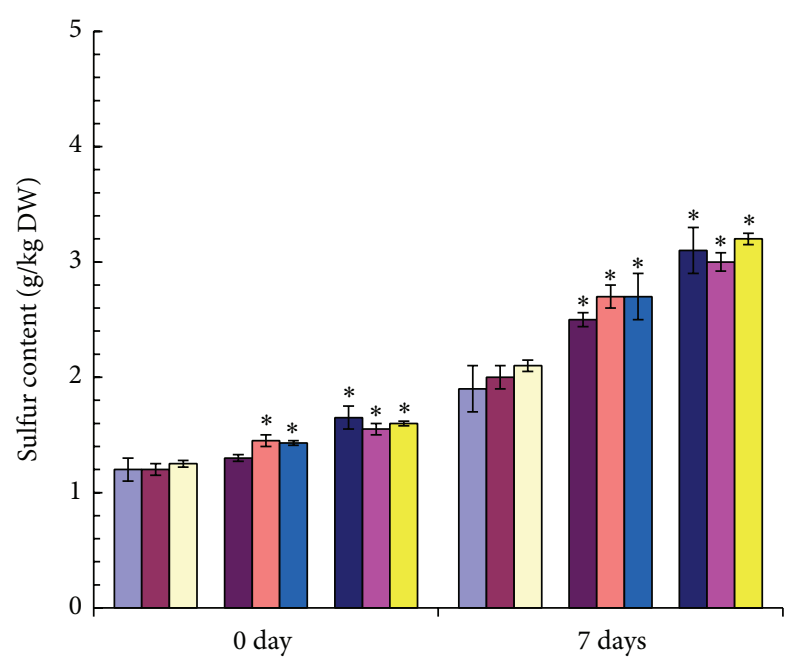

(a)

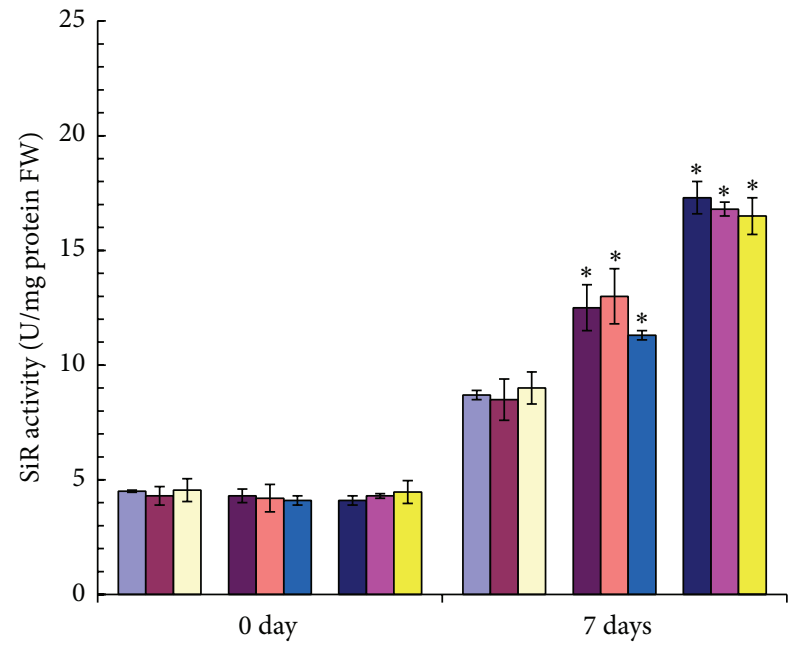

(b)

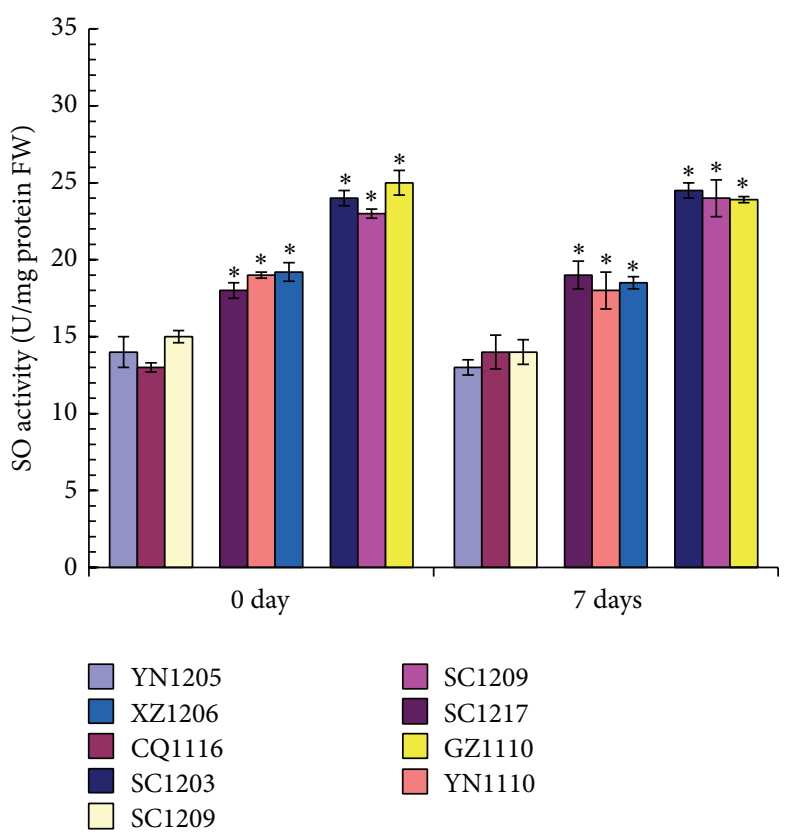

(c)

Figure 7: Comparison of sulfur contents (a), SiR activities (b), and SO activities (c) in leaves from nine selected C. dactylon accessions in response to $\mathrm{SO}_{2}$ stress. Mean values are presented with vertical error bars representing the standard deviations $(n=3)$. The asterisk symbols indicate significant differences between $\mathrm{SO}_{2}$-sensitive accessions and $\mathrm{SO}_{2}$-tolerant accessions.

C. dactylon accessions, consistent with previous reports on other plant species $[45,46]$. Under $\mathrm{SO}_{2}$ stress condition, the $\mathrm{SO}_{2}$-tolerant $C$. dactylon accessions showed higher levels of both $\mathrm{SiR}$ and $\mathrm{SO}$ activities and contained higher sulfur content in leaves as corresponding consequence. More importantly, we found that the $\mathrm{SO}_{2}$-tolerant $\mathrm{C}$. dactylon accessions showed significantly higher $\mathrm{SO}$ activities prior to $\mathrm{SO}_{2}$ treatment, but no significant differences were observed among the nine $C$. dactylon accessions. Increased $\mathrm{SO}$ activity in $\mathrm{SO}_{2}$-tolerant $C$. dactylon accession could convert sulfite to nontoxic sulfate more efficiently than $\mathrm{SO}_{2}$-sensitive $C$. dactylon accession for storage, once highly toxic $\mathrm{SO}_{2}$ gas enters into the $C$. dactylon cells, which indicates that SO antioxidant enzyme plays an important role in $\mathrm{SO}_{2}$ tolerance in C. dactylon.

\section{Conclusion}

C. dactylon, a warm season perennial grass species, is widely used as turfgrass on sports fields, golf courses, roadsides, and lawns in city or industry districts in warm season. Although this species has much better $\mathrm{SO}_{2}$-tolerant ability among warm season turfgrasses, its growth rate will be affected and visible symptoms like yellowing, chlorosis, bleaching, and even killing foliage will appear on leaves of C. dactylon in $\mathrm{SO}_{2}$ 
polluted areas. To achieve better air quality and landscape effect in $\mathrm{SO}_{2}$ polluted areas, selection or development of high $\mathrm{SO}_{2}$-tolerant $C$. dactylon variations is desired. In this study, we selected 9 out of $38 \mathrm{C}$. dactylon accessions from Southwest China as representatives of high, intermediate $\mathrm{SO}_{2}$-tolerant, and $\mathrm{SO}_{2}$-sensitive accessions and then comparatively analyzed their physiological differences under $\mathrm{SO}_{2}$ untreated and treated conditions. Our results indicated that $\mathrm{SO}_{2}$ tolerance of C. dactylon might be largely related to soluble sugar, proline and chlorophyll a contents, and SO enzyme activities. This study gained some insights into understanding the genetic and molecular $\mathrm{SO}_{2}$-tolerant mechanisms of $C$. dactylon and provided guideline for selection or development of $C$. dactylon variations for planting in $\mathrm{SO}_{2}$ polluted urban or industrial areas.

\section{Conflict of Interests}

The authors declare that there is no conflict of interests regarding the publication of this paper.

\section{Authors' Contribution}

$\mathrm{Xi} \mathrm{Li}$ and Ling Wang contributed equally to this paper.

\section{Acknowledgments}

This work was supported in part by the Science and Technology Department of Sichuan Province (Grant no. 05JY009007-4) and the Scientific Research Fund of Sichuan Provincial Education Department (Grant no. 12ZA116).

\section{References}

[1] D. M. Whelpdale, S. R. Dorling, B. B. Hicks, and P. W. Summers, "Atmospheric process," in Global Acid Deposition Assessment, D. M. Whelpdale and M. S. Kaiser, Eds., Report Number 106, pp. 7-32, World Meteorological Organization Global Atmosphere Watch, Geneva, Switzerland, 1996.

[2] Z. Lu, D. G. Streets, Q. Zhang et al., "Sulfur dioxide emissions in China and sulfur trends in East Asia since 2000," Atmospheric Chemistry and Physics, vol. 10, no. 13, pp. 6311-6331, 2010.

[3] Y. Zhao, J. Zhang, and C. P. Nielsen, "The effects of recent control policies on trends in emissions of anthropogenic atmospheric pollutants and $\mathrm{CO}_{2}$ in China," Atmospheric Chemistry and Physics, vol. 13, no. 2, pp. 487-508, 2013.

[4] L. P. Singh, S. S. Gill, R. Gill, and N. Tuteja, "Mechanism of sulfur dioxide toxicity and tolerance in crop pants," in Improving Crop Resistance to Abiotic Stress, N. Tuteja, A. F. Tiburcio, and R. Tuteja, Eds., pp. 133-163, Wiley-VCH Verlag GmbH \& Co. KGaA, Weinheim, Germany, 2012.

[5] H. Q. Lu and F. P. Liu, "A review of phytoremdiation to chemical air pollution and plant species selection for greening," Subtropical Plant Science, vol. 32, no. 3, pp. 73-77, 2003.

[6] C. S. Lee, K. S. Lee, J. K. Hwangbo, Y. H. You, and J. H. Kim, "Selection of tolerant plants and their arrangement to restore a forest ecosystem damaged by air pollution," Water, Air, \& Soil Pollution, vol. 156, no. 1-4, pp. 251-273, 2004.

[7] X. Zhang, P. Zhou, W. Zhang, W. Zhang, and Y. Wang, "Selection of landscape tree species of tolerant to sulfur dioxide pollution in subtropical China," Open Journal of Forestry, vol. 3, no. 4, pp. 104-108, 2013.

[8] U. Heber and K. Huve, "Action of $\mathrm{SO}_{2}$ on plants and metabolic detoxification of $\mathrm{SO}_{2}$," International Review of Cytology, vol. 177, pp. 255-286, 1997.

[9] M. Ayazloo and J. N. B. Bell, "Studies on the tolerance to sulphur dioxide of grass populations in polluted areas. I. Identification of tolerant populations," New Phytologist, vol. 88, no. 2, pp. 203$222,1981$.

[10] M. Ayazloo, S. G. Garsed, and J. N. B. Bell, "Studies on the tolerance to sulphur dioxide of grass populations in polluted areas. II. Morphological and physiological investigations," New Phytologist, vol. 90, no. 1, pp. 109-126, 1982.

[11] G. B. Wilson and J. N. B. Bell, "Studies on the tolerance to $\mathrm{SO}_{2}$ of grass populations in polluted areas. III. Investigations on the rate of development of tolerance," New Phytologist, vol. 100, no. 1, pp. 63-77, 1985.

[12] G. B. Wilson and J. N. B. Bell, "Studies on the tolerance to sulphur dioxide of grass populations in polluted areas. IV. The genetic nature of tolerance in Lolium perenne L.", New Phytologist, vol. 116, no. 2, pp. 313-317, 1990.

[13] L. H. Wang, X. Li, W. Liu, and Y. M. Gan, "A study on resistance and purifying ability of $\mathrm{SO}_{2}$ on four warm-season turfgrasses," Acta Prataculturae Sinica, vol. 22, no. 1, pp. 225-233, 2013.

[14] J. R. Harlan, "Cynodon and their value for grazing or hay," Herbage Abstracts, vol. 40, no. 3, pp. 233-238, 1970.

[15] S. Lu, C. Chen, Z. Wang, Z. Guo, and H. Li, "Physiological responses of somaclonal variants of triploid bermudagrass (Cynodon transvaalensis $\times$ Cynodon dactylon) to drought stress," Plant Cell Reports, vol. 28, no. 3, pp. 517-526, 2009.

[16] L. S. Bates, R. P. Waldren, and I. D. Teare, "Rapid determination of free proline for water-stress studies," Plant and Soil, vol. 39, no. 1, pp. 205-207, 1973.

[17] H. K. Lichtenthaler and A. R. Wellburn, "Determination of total carotenoids and chlorophylls a and b of leaf extracts in different solvents," Biochemical Society Transactions, vol.11, no. 5, pp. 591592,1983

[18] L. Hu, H. Li, H. Pang, and J. Fu, "Responses of antioxidant gene, protein and enzymes to salinity stress in two genotypes of perennial ryegrass (Lolium perenne) differing in salt tolerance," Journal of Plant Physiology, vol. 169, no. 2, pp. 146-156, 2012.

[19] M. M. Bradford, "A rapid and sensitive method for the quantitation of microgram quantities of protein utilizing the principle of protein dye binding," Analytical Biochemistry, vol. 72, no. 1-2, pp. 248-254, 1976.

[20] R. S. Dhindsa, P. Plumb-dhindsa, and T. A. Thorpe, "Leaf senescence: correlated with increased levels of membrane permeability and lipid peroxidation, and decreased levels of superoxide dismutase and catalase," Journal of Experimental Botany, vol. 32, no. 1, pp. 93-101, 1981.

[21] C. N. Giannopolitis and S. K. Ries, "Superoxide dismutases: I. Occurrence in higher plants," Plant Physiology, vol. 59, no. 2, pp. 309-314, 1977.

[22] C. R. Curtis, "Disc electrophoretic comparisons of protein and peroxidases from Phaseolus vulgaris leaves infected with Agrobacterium tumefaciens," Canadian Journal of Botany, vol. 49, no. 3, pp. 333-337, 1971.

[23] H. Aebi, "Catalase in vitro," Methods in Enzymology, vol. 105, pp. 121-126, 1984.

[24] W. Bosma, R. Schupp, L. J. Dekok, and H. Rennenberg, "Effect of selenate on assimilatory sulfate reduction and thiol content 
of spruce needles," Plant Physiology and Biochemistry, vol. 29, no. 2, pp. 131-138, 1991.

[25] M. S. Khan, F. H. Haas, A. A. Samami et al., "Sulfite reductase defines a newly discovered bottleneck for assimilatory sulfate reduction and is essential for growth and development in Arabidopsis thaliana," Plant Cell, vol. 22, no. 4, pp. 1216-1231, 2010.

[26] G. Brychkova, D. Yarmolinsky, Y. Ventura, and M. Sagi, "A novel in-gel assay and an improved kinetic assay for determining in vitro sulfite reductase activity in plants," Plant and Cell Physiology, vol. 53, no. 8, pp. 1507-1516, 2012.

[27] F. Pachmayr, Vorkommen und bestimmungen von schwefel in mineralwasser [Dissertation], University München, München, Germany, 1960.

[28] J. Fu and B. Huang, "Involvement of antioxidants and lipid peroxidation in the adaptation of two cool-season grasses to localized drought stress," Environmental and Experimental Botany, vol. 45, no. 2, pp. 105-114, 2001.

[29] M. Reyes-Díaz, C. Meriño-Gergichevich, E. Alarcón, M. Alberdi, and W. J. Horst, "Calcium sulfate ameliorates the effect of aluminum toxicity differentially in genotypes of highbush blueberry (Vaccinium corymbosum L.)," Journal of Soil Science and Plant Nutrition, vol. 11, no. 4, pp. 59-78, 2011.

[30] S. Assefa, C. M. Taliaferro, M. P. Anderson, B. G. de los Reyes, and R. M. Edwards, "Diversity among Cynodon accessions and taxa based on DNA amplification fingerprinting," Genome, vol. 42, no. 3, pp. 465-474, 1999.

[31] S. Kang, G. Lee, K. B. Lim et al., "Genetic diversity among Korean bermudagrass (Cynodon spp.) ecotypes characterized by morphological, cytological and molecular approaches," Molecules and Cells, vol. 25, no. 2, pp. 163-171, 2008.

[32] T. M. Farsani, N. Etemadi, B. E. Sayed-Tabatabaei, and M. Talebi, "Assessment of genetic diversity of bermudagrass (Cynodon dactylon) using ISSR markers," International Journal of Molecular Sciences, vol. 13, no. 1, pp. 383-392, 2012.

[33] Y. Ling, X. Q. Zhang, X. Ma, S. Y. Chen, T. T. Chen, and W. Liu, "Analysis of genetic diversity among wild bermudagrass germplasm from southwest China using SSR markers," Genetics and Molecular Research, vol. 11, no. 4, pp. 4598-4608, 2012.

[34] H. Shi, Y. Wang, Z. Cheng, T. Ye, and Z. Chan, "Analysis of natural variation in bermudagrass (Cynodon dactylon) reveals physiological responses underlying drought tolerance," PLoS ONE, vol. 7, no. 12, Article ID e53422, 2012.

[35] M. K. Uddin, A. S. Juraimi, M. R. Ismail, M. A. Hossain, R. Othman, and A. Abdul Rahim, "Physiological and growth responses of six turfgrass species relative to salinity tolerance," The Scientific World Journal, vol. 2012, Article ID 905468, 10 pages, 2012.

[36] N. Mohammadkhani and R. Heidari, "Drought-induced accumulation of soluble sugars and proline in two maize varieties," World Applied Sciences Journal, vol. 3, no. 3, pp. 448-453, 2008.

[37] H. Lodish, A. Berk, C. A. Kaiser et al., "Photosynthetics tages and light- absorbing pigments," in Molecular Cell Biology, W. H. Freeman and Company, New York, NY, USA, 7th edition, 2012.

[38] N. C. Panigrahi, B. B. Mishra, and B. K. Mohanty, "Effect of sulphur dioxide on chlorophyll content of two crop plants," Journal of Environmental Biology, vol. 13, no. 3, pp. 201-205, 1992.

[39] N. Hamid and F. Jawaid, "Effect of short-term exposure of two different concentrations of sulphur dioxide and nitrogen dioxide mixture on some biochemical parameter of soybean
(Glycine max (1.) Merr.)," Pakistan Journal of Botany, vol. 41, no. 5, pp. 2223-2228, 2009.

[40] N. R. Madamanchi and R. G. Alscher, "Metabolic bases for differences in sensitivity of two pea cultivars to sulfur dioxide," Plant Physiology, vol. 97, no. 1, pp. 88-93, 1991.

[41] F. X. Kong, W. Hu, S. Y. Chao, W. L. Sang, and L. S. Wang, "Physiological responses of the lichen Xanthoparmelia mexicana to oxidative stress of $\mathrm{SO}_{2}$," Environmental and Experimental Botany, vol. 42, no. 3, pp. 201-209, 1999.

[42] C. H. Foyer and G. Noctor, "Redox homeostasis and antioxidant signaling: a metabolic interface between stress perception and physiological responses," Plant Cell, vol. 17, no. 7, pp. 1866-1875, 2005.

[43] G. M. Abogadallah, "Antioxidative defense under salt stress," Plant Signaling and Behavior, vol. 5, no. 4, pp. 369-374, 2010.

[44] G. Brychkova, V. Grishkevich, R. Fluhr, and M. Sagi, "An essential role for tomato sulfite oxidase and enzymes of the sulfite network in maintaining leaf sulfite homeostasis," Plant Physiology, vol. 161, no. 1, pp. 148-164, 2013.

[45] G. Brychkova, Z. Xia, G. Yang et al., "Sulfite oxidase protects plants against sulfur dioxide toxicity," The Plant Journal, vol. 50, no. 4, pp. 696-709, 2007.

[46] C. Lang, J. Popko, M. Wirtz et al., "Sulphite oxidase as key enzyme for protecting plants against sulphur dioxide," Plant, Cell and Environment, vol. 30, no. 4, pp. 447-455, 2007.

[47] D. Yarmolinsky, G. Brychkova, R. Fluhr, and M. Sagi, "Sulfite reductase protects plants against sulfite toxicity," Plant Physiology, vol. 161, no. 2, pp. 725-743, 2013. 

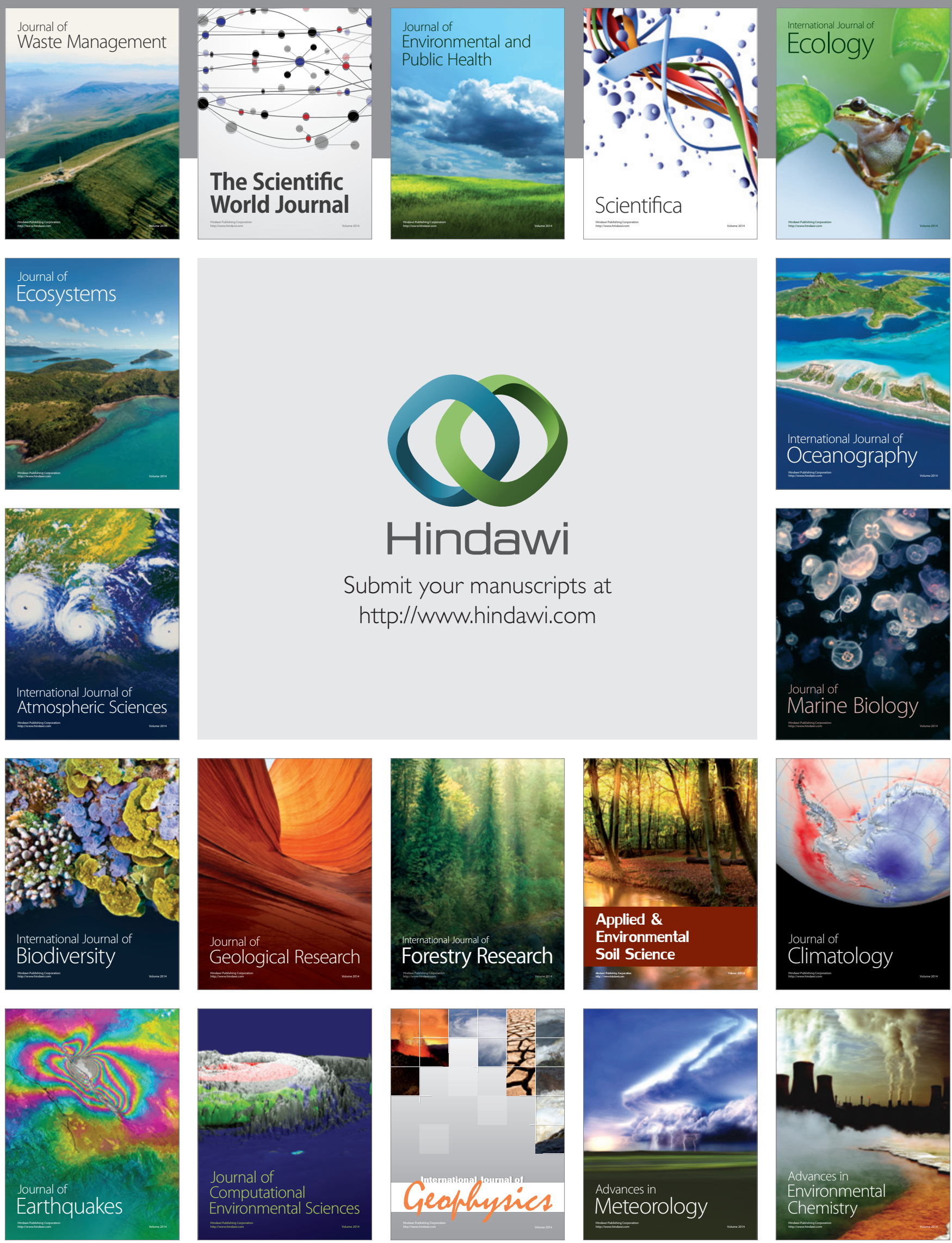